\section{WATERLOO AND ITS DENTAL LEGACY}

To commemorate the 200th anniversary since the Battle of Waterloo, the British Dental Association Museum is displaying its extensive collection of ivory dentures containing human teeth. Historians estimate that by the morning following the battle, the 50,000 bodies that lay dead or dying on the battlefield had been stripped of everything of value including their teeth.

Local scavengers, surviving soldiers and professional body scavengers were all known to work on the battlefield. Some body snatchers of London were known to get jobs following the British army. Transported back to England, the teeth were sold to the ivory turners and jewellers and those beginning to make a full-time living from the making of artificial teeth. Sorted and shaped, the teeth were riveted into a hippopotamus or walrus ivory base. Examples on display in the exhibition explore the methods and skill in how these human teeth were attached. The many processes involved ensured the denture took at least six weeks to complete. Not surprisingly they were very expensive to buy. In 1782 Martin Van Butchell of London advertised a full set of ivory dentures with human teeth for $£ 100$.

However, it wasn't long before an alternative to human teeth appeared on the market. Porcelain teeth had been introduced in
1808 but these 'bean teeth', as they were commonly known, were brittle and breakable. Claudius Ash disliked handling human teeth and set about improving the construction of the porcelain. Examples of C. Ash's early porcelain tube teeth are on display. These teeth could be fitted to an ivory or vulcanite denture. Despite these major developments it seems that the trade in human teeth continued and although references are few, dental manufacturing catalogues continued to sell human teeth in the late 1860s and analysis of Sir John Tomes' workbook, which is also on display, reveals that he was still using human teeth for attaching to partial gold dentures in the 1870s. The intriguing question is where were these teeth sourced from? Crimean War, American Civil War, or from the anatomy schools of London?

The exhibition opens on 18 June 2015 and runs until November 2015.

\section{BOOK REVIEW}

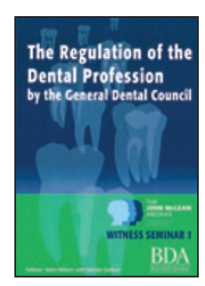

\section{THE REGULATION OF THE DENTAL PROFESSION BY THE GENERAL DENTAL COUNCIL N. Wilson, S. Gelbier BDA}

price €6.95; pp 98 ISBN 9781291723861

This handy sized book is the first in a series of five transcripts documenting witness seminars held at the British Dental Association. It gives an account of the regulation of the dental profession by the General Dental Council from a mixture of highly experienced individuals. The book begins by introducing members in attendance at the meeting, allowing the reader to understand and appreciate the great wealth of both knowledge and understanding of the regulatory body the attendees possess. Individuals have held many different positions including roles within the Royal College of Surgeons of England, the General Dental Council and the Department of Health.

The book then navigates into a structured discussion around the regulation of dentistry, ranging from regulation prior to and after the birth of the General Dental Council to the impact of regulation upon both the academic and clinical profession. Historical dates are utilised and interwoven into discussion to give a sense of the development time frame and the chronological order of significant events.

Overall, this is an exciting and innovative piece of literature, allowing members of the profession (and also non-professional members) to understand the history and development of the regulatory body of dentistry and will remain a valuable, timeless, literature piece.

H. MULLIN 